\title{
Prognostic value of hypocalcemia in COVID-19
}

\author{
Nasser Mikhail* and Soma Wali \\ Endocrinology Division, Department of Medicine, Olive-View-UCLA Medical Center, David-Geffen School of Medicine, CA, USA
}

\begin{abstract}
Background: Preliminary data suggest that hypocalcemia is common among patients with coronavirus 2019 (COVID-19) admitted to the hospital.

Objective: To examine the prognostic value of hypocalcemia in the setting of COVID-19.

Methods: Literature search (Pubmed) until September 15, 2020. Search terms include hypocalcemia, COVID-19, mortality, complications. Retrospective studies are reviewed due to lack of randomized trials.

Results: Hypocalcemia is the most common electrolyte abnormality in patients with COVID-19 admitted to the hospital after hyponatremia. Prevalence of hypocalcemia among hospitalized patients with COVID-19 ranges from $9.5 \%$ to $78 \%$ depending on the definition of hypocalcemia and patients' characteristics. In most cases, hypocalcemia is mild to moderate biochemically. Hypocalcemia is a risk factor for hospitalization of patients with COVID-19. In already hospitalized patients, hypocalcemia is significantly associated with increase severity of COVID-19 and its complications including multi-organ failure, intensive care unit (ICU) admission, need for mechanical ventilation, acute respiratory distress syndrome (ARDS), and death. Hypocalcemia is significantly correlated with inflammatory markers of COVID-19. Causes of hypocalcemia in COVID-19 patients are unclear, but vitamin D deficiency may be a contributing factor.
\end{abstract}

Conclusions: Hypocalcemia is common in hospitalized patients with COVID-19 and carries unfavorable outcomes. Further studies are needed to examine causes of hypocalcemia in COVID-19 and to see whether normalization of circulating calcium levels improve prognosis.

\section{Introduction}

COVID-19 is caused by a newly discovered coronavirus called severe acute respiratory syndrome coronavirus 2 (SARS-CoV-2). Shortly after many patients with COVID-19 were admitted to the hospital, few retrospective studies reported a high frequency of hypocalcemia (Table 1) [1-8]. The frequency of hypocalcemia in patients with COVID-19 admitted to the hospital ranges from 9.5 to $78 \%$ depending on its definition and patients' characteristics [1-8]. In one single Chinese cohort of 304 patients admitted to the hospital, only 22 patients (7\%) had hypocalcemia [9]. In the latter study, definition of hypocalcemia was not mentioned, and calcium values most likely were an outlier. In the report of Liu et al. [3], only 3 of 107 patients had severe hypocalcemia defined as ionized serum calcium of $<1.9$ $\mathrm{mmol} / \mathrm{L}$. In one series of 408 patients with COVID-19 admitted to the hospital, hyponatremia was the most common electrolyte abnormality occurring in $35.8 \%$ of patients followed by hypocalcemia occurring in $9.5 \%$ of patients [7].

\section{Mechanisms of hypocalcemia in COVID-19}

Causes of hypocalcemia in general are hypoparathyroidism, vitamin $\mathrm{D}$ deficiency, hypomagnesemia, and chronic kidney disease [10]. Hypoparathyroidism can be easily demonstrated by the finding of low or inappropriately normal plasma parathyroid hormone (PTH) levels in the face of hypocalcemia. Unfortunately, no studies assessed PTH values in patients with COVID-19 and hypocalcemia. Sun et al. [2] were the only investigators that measured PTH levels in a small subgroup of 26 patients among their cohort of 241 patients admitted with COVID-19. However, these 26 patients were not hypocalcemic. Likewise, vitamin D serum levels were measured in these 26 patients and were found to be low in all patients (Table 1) [2]. It is not known whether hypocalcemia plays a role in infection with the SARS-CoV-2. In fact, calcium ion was shown to be essential in fusion of coronavirus and its entry into host cells [11,12]. Therefore, it is tempting to speculate that "consumption" of circulating calcium for the sake of virus entry into host cells might contribute to hypocalcemia. Clearly, this hypothesis requires clarification by further investigations. It is also likely that hypocalcemia in hospitalized patients with COVID-19 and its association with more severe COVID-19 may be a marker of severe illness. Indeed, it was shown that hypocalcemia was common in patients with critical disease admitted to the ICU and was associated with poor prognosis [13].

\section{Impact of hypocalcemia on hospitalization}

In the series of 531 patients with COVID-19 reported by Di Filippo et al. [4], 424 (79.8\%) patients were admitted to the hospital. The authors found that serum calcium levels were significantly lower in patients requiring hospitalization than patients who were managed as outpatients. 1,13 and $1.16 \mathrm{mmol} / \mathrm{L}$, respectively $(\mathrm{P}<0.001)$ [4]. Moreover, by multivariate analysis, hypocalcemia emerged as independent risk factor for hospitalization, but not for death [4]. Furthermore, in the study of Wu et al. [5], hypocalcemia was independent risk factor for long-term hospitalization (defined as hospitalization longer than 14

${ }^{\star}$ Correspondence to: Nasser Mikhail, MD, MSc, Endocrinology Division, Department of Medicine, Olive-View-UCLA Medical Center, David-Geffen School of Medicine, CA, USA, E-mail:nmikhail@dhs.lacounty.gov

Key words: hypocalcemia, calcium, COVID-19, parathyroid hormone, vitamin D, mortality, prognosis

Received: August 09, 2020; Accepted: August 28, 2020; Published: August 31, 2020 
days); odds ratio 3.3, 95\% CI, 1.4-7.9). Likewise, in their case series from Turkey, Tezcan et al. [7] reported that hypocalcemia was associated with more prolonged hospitalization, with odds ratio (OR) of $1.08(95 \%$ CI 1.04-1.12; $\mathrm{P}<0.001)$.

\section{Impact of hypocalcemia on severity of COVID-19}

Sun et al. [2] found that COVID-19 patients with hypocalcemia (total serum calcium $<2.0 \mathrm{mmol} / \mathrm{L}$ ) developed the following complications: $32.6 \%$ had multiple organ dysfunction, $14.0 \%$ had septic shock, and $16.3 \%$ had cardiac injury, whereas none of patients with normal serum calcium $(>2.2 \mathrm{mmol} / \mathrm{L})$ developed any of these complications. Moreover, in the hypocalcemic group of patients, $34.9 \%$ had ARDS compared with only $1.6 \%$ in the normocalcemic group [2]. In their pooled analysis of 2 small Chinese studies, Lippi et al. [6] found significantly lower serum calcium levels in patients with severe COVID-19 compared with non-severe disease, weighted mean difference being $0.2 \mathrm{mmol} / \mathrm{L}, 95 \% \mathrm{CI}-0.25$ to -0.20 ). In the latter study, severe COVID-19 was defined as patients requiring mechanical ventilation, vital life support or ICU admission [2]. In the series of 408 patients reported by Tezcan et al. [7], these researchers found that hypocalcemia was associated with approximately 5 -fold increase risk of ICU admission and need for mechanical ventilation (Table 1).

Table 1. Retrospective studies that evaluate hypocalcemia in COVID-19

\begin{tabular}{|c|c|c|c|c|c|c|c|c|}
\hline Study & Cappellini et al. [1] & Sun et al. [2] & Liu et al. [3] & $\begin{array}{l}\text { De Filippo et } \\
\text { al. [4] }\end{array}$ & Wu et al. [5] & Lippi et al. [6] & Tescan et al. [7] & Khamis et al. [8] \\
\hline $\begin{array}{c}\text { Patients' } \\
\text { characteristics }\end{array}$ & $\begin{array}{l}\mathrm{N}=585,34 \% \text { women, } \\
\text { median age } 66 \text { years. } \\
420 \text { patients positive } \\
\text { for COVID- } 19\end{array}$ & $\begin{array}{c}\mathrm{N}=241,53 \% \\
\text { women, median } \\
\text { age } 65 \text { years }\end{array}$ & $\begin{array}{c}\mathrm{N}=107,51 \% \\
\text { women, median } \\
\text { age } 68 \text { years }\end{array}$ & $\begin{array}{c}\mathrm{N}=531,32 \% \\
\text { women, median } \\
\text { age } 59 \text { years, } 424 \\
(79.8 \%) \text { patients } \\
\text { were hospitalized }\end{array}$ & $\begin{array}{c}\mathrm{N}=125,47 \% \\
\text { women, median } \\
\text { age } 55 \text { years }\end{array}$ & $\begin{array}{l}\mathrm{N}=140 \text { pooled } \\
\text { from } 2 \text { studies. }\end{array}$ & $\begin{array}{c}\mathrm{N}=408,54 \% \\
\text { women, mean } \\
\text { age }( \pm \mathrm{SD}) 54 \pm 16 \\
\text { years }\end{array}$ & $\begin{array}{c}\mathrm{N}=63,15 \% \\
\text { women, mean age } \\
( \pm \mathrm{SD}) 48 \pm 16\end{array}$ \\
\hline $\begin{array}{c}\text { Type of measured } \\
\text { serum } \mathrm{Ca}\end{array}$ & Total and ionized $\mathrm{Ca}$ & $\begin{array}{c}\text { Total } \mathrm{Ca} \text {, not } \\
\text { albumin-corrected }\end{array}$ & $\begin{array}{l}\text { Total Ca corrected } \\
\text { for serum albumin }\end{array}$ & Ionized $\mathrm{Ca}$ & $\begin{array}{l}\text { Total } \mathrm{Ca}, \text { not } \\
\text { corrected for } \\
\text { albumin }\end{array}$ & $\begin{array}{l}\text { Total } \mathrm{Ca}, \text { not } \\
\text { corrected for } \\
\text { albumin }\end{array}$ & $\begin{array}{l}\text { Total Ca not } \\
\text { corrected for } \\
\text { albumin }\end{array}$ & $\begin{array}{l}\text { Total Ca corrected } \\
\text { for albumin }\end{array}$ \\
\hline $\begin{array}{c}\text { Definition of } \\
\text { hypocalcemia }\end{array}$ & NR & $\begin{array}{c}\text { Total } \mathrm{Ca} \leq 2.2 \\
\mathrm{mmol} / \mathrm{L}(\mathrm{n}=43)\end{array}$ & $\begin{array}{l}\text { Albumin-corrected } \\
\mathrm{Ca}<2.15 \mathrm{mmol} / \mathrm{L}\end{array}$ & $\begin{array}{c}\text { Ionized } \mathrm{Ca}<1.18 \\
\mathrm{mmol} / \mathrm{L}\end{array}$ & $\begin{array}{c}\text { Total } \mathrm{Ca}<2.2 \\
\mathrm{mmol} / \mathrm{L}\end{array}$ & NR & $\begin{array}{c}\text { Total calcium }<2.1 \\
\mathrm{mmol} / \mathrm{L}\end{array}$ & $\begin{array}{l}\text { Albumin-corrected } \\
\mathrm{Ca} \leq 2.15 \mathrm{mmol} / \mathrm{L}\end{array}$ \\
\hline $\begin{array}{l}\text { Proportions of } \\
\text { patients with } \\
\text { hypocalcemia }\end{array}$ & NR & $74.7 \%$ & $62 \%$ & $78.6 \%$ & $64.8 \%$ & NR & $9.5 \%$ & $48 \%$ \\
\hline $\begin{array}{l}\text { Results (all serum } \\
\mathrm{Ca} \text { are in } \mathrm{mmol} / \mathrm{L} \text { ) }\end{array}$ & $\begin{array}{l}\text { Total Ca (median, } \\
95 \% \mathrm{CI}=2.14 \\
(2.13-2.15) \text { in } \\
\text { COVID-19 vs } 2.27 \\
(2.25-2.29) \text { in non- } \\
\text { COVID-19. Ionized } \\
\text { Ca } 1.12(1.12-1.13) \\
\text { in COVID-19 vs } \\
1.17(1.16-1.19), \mathrm{P} \\
<0.0001 \text { for both } \\
\text { comparisons. }\end{array}$ & $\begin{array}{c}\text { Significantly } \\
\text { higher mortality } \\
\text { and multiorgan } \\
\text { failure in patients } \\
\text { with hypocalcemia }\end{array}$ & $\begin{array}{c}\text { Patients with poor } \\
\text { outcomes (defined } \\
\text { as death, admission } \\
\text { to intensive care } \\
\text { or mechanical } \\
\text { ventilation) had } \\
\text { lower median Ca } \\
\text { compared with } \\
\text { patients with } \\
\text { favorable outcome, } \\
2.01 \text { and } 2.10, \\
\text { respectively }(\mathrm{P}< \\
0.001)\end{array}$ & \begin{tabular}{|c|} 
Hospitalized \\
patients had lower \\
calcium than \\
non-hospitalized \\
patients, 1.13 and \\
1.16 , respectively, \\
$\mathrm{P}<0.001$. In \\
multivariate \\
analysis, \\
hypocalcemia \\
was independent \\
risk factor for \\
hospitalization (P< \\
0.001 ), but not for \\
death.
\end{tabular} & $\begin{array}{c}\text { Hypocalcemia } \\
\text { was independent } \\
\text { risk factor } \\
\text { for long-term } \\
\text { hospitalization }> \\
14 \text { days (odds ratio } \\
3.3,95 \% \text { CI, 1.4- } \\
7.9 ; \mathrm{P}=0.007 \text { ) }\end{array}$ & $\begin{array}{c}\text { Significantly lower } \\
\text { calcium in patients } \\
\text { with severe vs non- } \\
\text { severe COVID- } 19 \text {. } \\
\text { Weighted mean } \\
\text { difference }-0.2 \\
\text { mmol/L }(95 \% \mathrm{CI} \\
-0.25 \text { to }-0.20)\end{array}$ & $\begin{array}{c}\text { Hypocalcemia } \\
\text { associated with } \\
\text { ICU admission OR } \\
5.1,(95 \% \text { CI, } 2.3- \\
11.5) \text {, mechanical } \\
\text { ventilation OR } 5.2 \\
\text { (95\% CI } 2.1-12.5) \text {, } \\
\text { mortality OR 5.1 } \\
\text { (95\% CI } 2.1-12.8) \\
\text { and duration of } \\
\text { hospitalization OR } \\
1.08(95 \% \text { CI } 1.04- \\
1.12)\end{array}$ & $\begin{array}{c}15 \% \text { of patients } \\
\text { with hypocalcemia } \\
\text { died vs. none } \\
\text { in patients with } \\
\text { normal Ca } \\
(\mathrm{P}=0.047) .\end{array}$ \\
\hline $\begin{array}{c}\text { Median } \\
\text { parathyroid } \\
\text { hormone }(\mathrm{PTH}) \\
\text { (normal range } 15- \\
65 \mathrm{pg} / \mathrm{ml})\end{array}$ & NR & $\begin{array}{c}\text { Measured in } 26 \\
\text { patients: } 55.3 \\
\text { pg/ml }\end{array}$ & NR & NR & NR & NR & NR & NR \\
\hline $\begin{array}{c}\text { Median } 25 \mathrm{OH} \\
\text { Vitamin D (normal } \\
\text { range } 30-80 \mathrm{ng} / \mathrm{ml})\end{array}$ & NR & $\begin{array}{c}\text { Measured in } 26 \\
\text { patients } 10.2 \mathrm{ng} / \\
\text { ml. All } 26 \text { patients } \\
\text { had low } 25 \mathrm{OH} \\
\text { vitamin D levels: } \\
\text { *IQR } 8.2-12.6) \\
\mathrm{ng} / \mathrm{ml} .\end{array}$ & NR & NR & NR & NR & NR & NR \\
\hline $\begin{array}{c}\text { Significant } \\
\text { association of } \\
\text { hypocalcemia } \\
\text { with inflammatory } \\
\text { markers }\end{array}$ & NR & $\begin{array}{l}\text { C-reactive protein, } \\
\text { D-dimer (negative } \\
\text { correlation), } \\
\text { lymphocyte } \\
\text { count (positive } \\
\text { correlation) }\end{array}$ & $\begin{array}{c}\text { Hypocalcemic } \\
\text { patients had } \\
\text { higher C-reactive } \\
\text { protein, D-dimer, } \\
\text { pro-calcitonin, } \\
\text { interleukin-6, and } \\
\text { leukocyte count } \\
\text { vs normocalcemic } \\
\text { patients }\end{array}$ & $\begin{array}{l}\text { Negative } \\
\text { correlation of } \\
\text { serum Ca with } \\
\text { C-reactive } \\
\text { protein, lactate } \\
\text { dehydrogenase } \\
\quad(\mathrm{LDH})\end{array}$ & NR & NR & NR & NR \\
\hline
\end{tabular}

Normal total serum calcium: $2.15-2.50 \mathrm{mmol} / \mathrm{L}$. To convert to $\mathrm{mg} / \mathrm{dl}$, multiply by 4 .

Normal range of serum ionized calcium was not reported in the studies. In general, range of ionized calcium: 1.2-1.4 mmol/L.

SD: Standard deviation

NR: Not reported.

*IQR: Inter-quartile range 


\section{Impact of hypocalcemia on mortality in COVID-19}

Sun et al. [2] reported $23.3 \%$ mortality rate in patients with COVID-19 and hypocalcemia having median total calcium $1.96 \mathrm{mmol} / \mathrm{L}$ [inter-quartile range (IQR) 1.90-2.00] compared to no mortality among patients with normal serum calcium values. In agreement with these results, Liu et al. [3] found that COVID-19 patients with poor outcomes (defined as death, admission to ICU or need for mechanical ventilation) had lower serum calcium concentrations compared with patients with favorable outcome, 2.01 and $2.10 \mathrm{mmol} / \mathrm{L}$, respectively $(\mathrm{P}<0.001)$. In the study of Tezcan et al. [7], hypocalcemia was associated with significant increase risk of death (OR 5.14, 95\% CI 2.0-12.2; $\mathrm{P}<0.001$ ). Furthermore, in the series of Khamis et al. [8], 15\% of patients with hypocalcemia died compared with none among patients with normal serum calcium ( $\mathrm{P}=0.047)$ (Table1).

\section{Relationship of hypocalcemia to inflammatory markers in COVID-19}

Multiple studies have shown significant association between hypocalcemia and inflammatory markers that reflect severity of COVID-19. Thus, there was significant negative correlation between hypocalcemia and plasma levels of C-reactive protein [2,4], lactic dehydrogenase (LDH) [4] and D-dimer (Table 1) [2,4]. In addition, patients with hypocalcemia had higher circulating interleukin-6 and pro-calcitonin compared with normocalcemic patients [3].

\section{Potential complications of hypocalcemia in hospitalized patients with COVID-19}

In most patients with COVID-10 reported in the literature, hypocalcemia was mild to moderate biochemically [1-8]. To the best of the authors' knowledge, so far, no cases of hospitalized COVID-19 patients experienced neurological symptoms of hypocalcemia such as tetany or seizures. Meanwhile, it is known that hypocalcemia is associated with prolongation of QT interval, which is proportional to the degree of hypocalcemia and may cause life threatening torsade de pointes [14]. Interestingly, in one study, 48.5\% (50 of 103) patients with COVID-19 with prolonged QT interval had electrolyte abnormalities [15]. Thus, in these patients, hypomagnesemia was recorded in $30.1 \%$ of patients and hypokalemia in $27 \%$ [15]. Unfortunately, calcium levels were not reported [15].

\section{Conclusions and current needs}

Hypocalcemia commonly occurs in hospitalized patients with COVID-19 and carries unfavorable prognosis. Etiology of hypocalcemia in patients with COVID-19 is still unclear but is likely multifactorial. Further studies are urgently needed to examine causes of hypocalcemia in hospitalized patients with COVID-19. Measurement of ionized serum calcium should be done because it is more accurate than albumin-corrected calcium in critically ill patients [16]. In addition, plasma levels of $\mathrm{PTH}$, magnesium, and 25-hydroxy vitamin
D levels should be measured in all patients with hypocalcemia to clarify the etiology of hypocalcemia. Randomized trials are required to see whether correction of hypocalcemia would lead to improvement of outcomes.

\section{Conflict of interest}

The authors do not have any conflict of interest to declare.

\section{References}

1. Cappellini F, Brivio R, Casati M, Cavallero A, Contro E, et al. (2020) Low levels of total and ionized calcium in blood of COVID-19 patients. Clin Chem Lab Med 58: e171-e173. [Crossref]

2. Sun J, Zhang W, Zou L, Liu Y, Li JJ, et al. (2020) Serum calcium as a biomarker of clinical severity and prognosis in patients with coronavirus disease 2019. Aging 12 : 11287-11295. [Crossref]

3. Liu J, Han P, Wu J, Gong J, Tian D (2020) Prevalence and predictive value of hypocalcemia in severe COVID-19 patients. J Inf Pub Health 13: 1224-1228. [Crossref]

4. Di Filippo L, Formenti AM, Rovere-Querini P, Carlucci M, Conte C, et al. (2020) Hypocalcemia is highly prevalent and predicts hospitalization in patients with COVID-19. Endocrine 68: 475-478. [Crossref]

5. Wu Y, Hou B, Liu J, Chen Y, Zhong P (2020) Risk factors associated with long-term hospitalization in patients with COVID-19: a single-centered, retrospective study. Frontiers Med 7: 315. [Crossref]

6. Lippi G, South AM, Henry BM (2020) Electrolyte imbalances in patients with severe coronavirus disease 2019 (COVID-19). Ann Clin Biochem 57: 262-265. [Crossref]

7. Tezcan ME, Dogan Gokce G, Sen N, Zorlutuna Kaymak N, Ozer RS (2020) Baseline electrolyte abnormalities would be related to poor prognosis in hospitalized COVID-19 patients. New Microbes New Infect. [Crossref]

8. Khamis F, Al-Zakwani I, Al Naamani H, Al Lawati S, Pandak N, et al. (2020) Clinical characteristics and outcomes of the first 63 adult patients hospitalized with COVID-19: An experience from Oman. J Infect Public Health 13: 906-913. [Crossref]

9. Lu L, Xiong W, Liu D, Liu J, Yang D, et al. (2020) New onset acute symptomatic seizures and risk factors in coronavirus disease 2019. A retrospective multicenter study. Epilipsia. [Crossref]

10. Bove-Fenderson E, Mannstadt M (2018) Hypocalcemic disorders. Best Pract Res Clin Endocrinol Metab 32: 639-656. [Crossref]

11. Millet JK, Whitaker GR (2018) Physiological and molecular triggers for SARS-CoV membrane fusion and entry into host cells. Virology 517: 3-8. [Crossref]

12. Strauss MR, Tang AL, Lai AL, Flegel A, Bidon M, et al. (2020) Ca2+ ions promote fusion of Middle East respiratory syndrome coronavirus with host cells and increase infectivity. J Virol 94: e00426-20. [Crossref]

13. Sanaie S, Mahmoodpoor A, Hamishekar H, Shadvar K, Salimi N, et al. (2018) Association between disease severity and calcium concentration in critically ill patients admitted to intensive care unit. Anesth Pain Med 8: e57583. [Crossref]

14. Chabra ST, Mehta S, Chabra S, Singla M, Aslam N, et al. (2018) Hypocalcemia presenting as life threatening torsades de pointes with prolongation of QTc interval. Int J Clin Biochem 33: 235-238. [Crossref]

15. Jain S, Workman V, Ganeshan R, Obasare ER, Burr A, et al. (2020) Enhanced electrocardiographic monitoring of patients with coronavirus disease 2019. Heat Rhythm 17:1417-1422. [Crossref]

16. Hu ZD, Huang YL, Wang MY, Hu GJ, Han YQ (2018) Predictive accuracy of serum total calcium for both critically high and critically low ionized calcium in critical illness. J Clin Lab Anal 32: e22589. [Crossref]

Copyright: $\odot 2020$ Mikhail N. This is an open-access article distributed under the terms of the Creative Commons Attribution License, which permits unrestricted use, distribution, and reproduction in any medium, provided the original author and source are credited. 